\title{
A Multivariate Long-Run Money Neutrality Investigation: Empirical Evidence for CAMEU
}

\author{
Jean-Jacques Tony Ekomie \\ Department of Economics, Omar Bongo University, Libreville, Gabon \\ Email: jjekomie@yahoo.fr
}

Received January 10, 2013; revised February 10, 2013; accepted March 10, 2013

Copyright (c) 2013 Jean-Jacques Tony Ekomie. This is an open access article distributed under the Creative Commons Attribution License, which permits unrestricted use, distribution, and reproduction in any medium, provided the original work is properly cited.

\begin{abstract}
We examine the long run neutrality of money, in Central Africa Monetary and Economic Union (CAMEU) economies applying the multivariate methodology of King and Watson, using M2 and real output during the period 1970-2008. Tests consistently reject the long run money neutrality hypothesis. It is found that M2 has significant and positive impacts on real output of all CAMEU countries except for Gabon. The results are robust under other monetary aggregate variables and various sub-periods. In addition, the estimated coefficients are stable under two breakpoints corresponding to the dates of central bank reforms and devaluation of the local currency.
\end{abstract}

Keywords: Long Run Money Neutrality; CAMEU Countries; A Multivariate Methodology

\section{Introduction}

The hypothesis of long-run neutrality of money, i.e., the absence of long-term effects of money supply on the production level is widely accepted in modern macroeconomics since the work of [1-4]. Indeed, as the velocity of money is constant and that of the activity is constrained by the capacity to supply goods, changes in the money supply lead to price changes. This leads [1] asserted that "inflation is always and everywhere a monetary phenomenon". Moreover, according to the authors of the New Classical Economics, perfectly anticipated monetary policy has no effect, even in the short term on the activity. Thus, permanent changes in the level of money supply do not affect real variables in the long term ([5-7]). However, [8] noted that the test of this proposal is subtle since [9] provides an example in which it is impossible to test the long-run neutrality using a reduced form model: it is a rational expectations model integrating rational expectations with non-neutrality in the short term and exogenous variables which follow stationary processes. Thus, the data generated by this model are not likely to contain sustainable changes necessary to directly test the long-run money neutrality hypothesis.

Despite this example, [9] argues that it is necessary to build fully articulated behavioral models to test the neutrality hypothesis. The specific criticism developed focuses on the issue of stationarity. Indeed, in models in which nominal variables are integrated, the long-run neutrality can be defined and tested without a complete knowledge of the model. But even when the variables are integrated, neutrality long term cannot be tested using a reduced-form model. Instead, it is necessary to test the model of "final form", highlighting the dynamic response variables underlying structural disturbances.

Taking into account this assumption, [8] show that the test of neutrality can be built if the nominal and real variables satisfy certain non-stationarity conditions. The fundamental reason is that monetary neutrality induces permanent changes in the level of money and cannot effectively be tested without strong evidence that the current level of money supply is affected by permanent changes.

Several studies used the long-term neutrality testing procedure developed by [8]. [10], for example, show that the long-run neutrality can be tested with limited structural information when nominal variables are integrated. Using quarterly data from Japan, Sweden and Italy, they test the long-term neutrality hypothesis between the inflation and the nominal interest rates. Similarly, Chen [11], in order to test the hypothesis of long-term money neutrality using quarterly data for South Korea and Taiwan, pay particular attention to the stationarity and cointegration of the variables involved. They show that the test procedure of long run neutrality cannot be performed if the variables are not cointegrated. Based on 
the estimated results, the hypothesis of long-run neutrality of money with respect to the actual output is supported in the case of South Korea, but is rejected in the case of Taiwan.

In Africa, [12] analyzes the impact of the hypothesis of money neutrality in the Franc zone. The analytical framework used by the author is the same as mentioned by [8]. However, to account for bias due to omission of certain variables, the author introduced in the model some key interest rates and inflation variables. Using quarterly data covering the period 1994:Q2-2006:Q4, the author observes a trend towards long run non-neutrality of money in Senegal and Cote-d'Ivoire.

In this paper, to investigate the hypothesis of long-run neutrality between monetary aggregates and real output in $\mathrm{CAMEU}^{1}$, we consider the methodology developed by [8]. The paper endeavors to fill a gap as most empirical studies on long-run neutrality of money have focused on industrialized economies with very little attention, if any, to developing countries.

The remainder of the paper is organized as follows: Section 2 develops the multivariate econometric methodology. Section 3 is related to empirical estimation results. Section 4 concludes the paper.

\section{Multivariate Econometric Methodology}

First, we consider the simultaneous equations models developed by [8]. The model is of order $p$ and is defined in first differences. To estimate the long run effect of nominal money supply $\left(m_{t}\right)$ on real output $\left(y_{t}\right)$, the fol- lowing model is used,

$$
\begin{gathered}
\Delta m_{t}=\lambda_{m y}+\sum_{j=1}^{p} \alpha_{j, m y} \Delta y_{t-j}+\sum_{j=1}^{p} \alpha_{j, m m} \Delta m_{t-j}+\varepsilon_{t}^{m} \\
\Delta y_{t}=\lambda_{y m}+\sum_{j=1}^{p} \alpha_{j, y y} \Delta y_{t-j}+\sum_{j=1}^{p} \alpha_{j, y m} \Delta m_{t-j}+\varepsilon_{t}^{y}
\end{gathered}
$$

where $\varepsilon_{t}^{m}$ and $\varepsilon_{t}^{y}$ are respectively structural shocks of money supply and real output which can have permanent effects on the levels of the endogenous variables $m_{t}$ and $y_{t}$.

In vector form, the above equations can be written as,

$$
\alpha(L) X_{t}=\varepsilon_{t}
$$

where $\alpha(L)=\sum_{j=0}^{p} \alpha_{j} L^{j}$ and $X_{t}=\left[\begin{array}{c}\Delta m_{t} \\ \Delta y_{t}\end{array}\right], \quad \varepsilon_{t}=\left[\begin{array}{c}\varepsilon_{t}^{m} \\ \varepsilon_{t}^{y}\end{array}\right]$,

$$
\alpha_{0}=\left[\begin{array}{cc}
1 & -\lambda_{y m} \\
-\lambda_{y m} & 1
\end{array}\right], \quad j=1, \cdots, p
$$

Our objective is to analyze the long run effect of

${ }^{1}$ CAMEU: Cameroon, Central African Republic, Chad, Congo, Gabon and Guinea Equatorial. monetary shock $\varepsilon_{t}^{m}$ on the real output $y_{t}$. We can express this by using the long run multiplier:

$$
\gamma_{y m}=\frac{\alpha_{y m}(1)}{\alpha_{y y}(1)}
$$

where $\gamma_{y m}$ gives the percentage of increase in real output for each point of increase in the percentage of the nominal money supply resulting from a permanent monetary shock. In this case, the money supply long run neutrality implies the condition: $\gamma_{y m}=0$.

In their study, [8] show that the endogeneity of $m_{t}$ and $y_{t}$ implies that equation (3) is non-identified econometrically. This can easily be seen by re-writing the reduced form as,

$$
X_{t}=\sum_{j=1}^{p} \phi_{j} X_{t-j}+e_{t}
$$

where $\phi_{j}=-\alpha_{0}^{-1} \alpha_{j}$ and $e_{t}=-\alpha_{0}^{-1} \varepsilon_{t} \quad e_{t}=-\alpha_{0}^{-1} \varepsilon_{t}$. The matrices $\alpha$ and $\sum_{\alpha}$ are obtained from the following equations,

$$
\begin{gathered}
-\alpha_{0}^{-1} \alpha_{j}=-\phi_{j} \text { with } j=1, \cdots, p \\
\alpha_{0}^{-1} \sum_{\alpha}\left(\alpha_{j}\right)^{t}=\sum_{e}
\end{gathered}
$$

Equation (5) determines $\phi_{j}$ as a function of $\alpha_{0}$ and $\alpha_{i}$. Equation (6) determines $\sum_{\alpha}$ from $\alpha_{0}$ and $\sum_{\alpha}$. $\sum_{e}$ is a symmetric $\sum_{\alpha}(2 \times 2)$ matrix with three unique elements. Thus, since $\varepsilon_{t}^{m}$ and $\varepsilon_{t}^{y}$ are independent, we identify only three unknown parameters: $\lambda_{\text {my }}, \lambda_{y m}, \operatorname{Var}\left(\varepsilon_{t}^{m}\right)$ and $\operatorname{Var}\left(\varepsilon_{t}^{y}\right)$. Another restriction is therefore needed in order to completely identify the model.

To get an appropriate estimation of the model, we adopt the approach of [8]. They assume known by a parallel study or equalization to zero in the context of a bivariate VAR:

- The impact elasticity of a monetary indicator with respect to the revenue or;

- The impact elasticity of revenue with respect to a monetary indicator or;

- The long run elasticity of this indicator with respect to the output or finally;

- The long run elasticity of the output with respect to the same indicator.

In our framework, the estimated value of the long-run elasticity of output with respect to money depends mainly on what is assumed about the elasticities of the other three elasticities: 1) the impact elasticity of production with respect to money; 2) the impact elasticity of money with respect to production; or 3) the long run elasticity of money with respect to the output.

We present the results of tests of neutrality for a wide range of values for these elasticities, using graphical methods. 


\section{Data and Results}

\subsection{Data}

In our study, we use annual data on the actual product at constant prices and the value of the real money supply $m_{2}$ over the period 1970-2008 for each of the following countries: Cameroon, Central African Republic, Chad, Congo and Gabon. Guinea Equatorial was excluded because of data availability. Data are taken from the World Development Indicators (WDI) database.

\subsubsection{Unit Root Test}

Before any regression, it is customary to identify whether the selected series have unit roots. To verify this, we used three tests: the ADF test (Augmented DickeyFuller), the PP (Phillips-Perron) test and the KPSS test (Kwiatkowski-Phillips-Schmidt-Shin). The tests are made on the basis of the model with constant, and constant and trend.

The results of the tests in level, presented in Table 1(a), do not allow us to conclude that the series are stationary. As for the tests in first difference, the results are presented in Table 1(b), they indicate that the null hypothesis of unit root is rejected for both variables $m_{t}$ and $y_{t}$ in the five countries. Thus the series are $I(1)$.

Tableau 1. (a) Unit root test in level; (b) Unit root test in first differences.

(a)

\begin{tabular}{|c|c|c|c|c|c|c|c|c|c|}
\hline \multirow{2}{*}{ PAYS } & \multirow{2}{*}{ Variables } & \multicolumn{3}{|c|}{ ADF } & \multicolumn{3}{|c|}{ PP } & \multicolumn{2}{|c|}{ KPSS } \\
\hline & & Model 3 & Model 2 & Model 1 & Model 3 & Model 2 & Model 1 & Model 3 & Model 2 \\
\hline \multirow{2}{*}{ CAMEROUN } & $\operatorname{lm} 2 \_c m r$ & 0.5982 & 0.3915 & 0.9519 & 0.6779 & 0.3523 & 0.9777 & 0.13 & 0.432 \\
\hline & lpib_cmr & 0.0536 & 0.315 & 0.9881 & 0.7177 & 0.371 & 0.9961 & 0.1367 & 0.6302 \\
\hline \multirow{2}{*}{ GABON } & $\operatorname{lm} 2$ gab & 0.0336 & 0.0309 & & 0.1913 & 0.0649 & 0.9991 & 0.15212 & 0.709 \\
\hline & lpib_gab & 0.101 & 0.0411 & 0.9838 & 0.0712 & 0.0298 & 0.9736 & 0.0916 & 0.7559 \\
\hline \multirow{2}{*}{ CONGO } & $\operatorname{lm} 2$ _congo & 0.7598 & 0.8832 & 0.9999 & 0.7263 & 0.8852 & & 0.126 & 0.731 \\
\hline & lpib_congo & 0.4505 & 0.4868 & 0.9819 & 0.6392 & 0.3324 & 0.9987 & 0.1574 & 0.6945 \\
\hline \multirow{2}{*}{ TCHAD } & lm2_tchad & 0.3248 & 0.9221 & 0.9999 & 0.6574 & 0.9326 & & 0.1135 & 0.7465 \\
\hline & lpib_tchad & 0.8198 & 0.9932 & 0.9925 & 0.7723 & 0.9928 & 0.9866 & 0.1738 & 0.6735 \\
\hline \multirow{2}{*}{ RCA } & lm2_rca & 0.8045 & 0.2197 & 0.9993 & 0.8478 & 0.0347 & 0.9989 & 0.177 & 0.702 \\
\hline & lpib_rca & 01707 & 0.6744 & 0.9767 & 0.1359 & 0.7116 & 0.9904 & 0.0605 & 0.7313 \\
\hline \multirow{2}{*}{ countries } & \multirow{2}{*}{ Variables } & \multicolumn{3}{|c|}{ ADF } & \multicolumn{3}{|c|}{ PP } & \multicolumn{2}{|c|}{ KPSS } \\
\hline & & Model 3 & Model 2 & Model 1 & Model 3 & Model 2 & Model 1 & Model 3 & Model 2 \\
\hline \multirow{2}{*}{ CAMEROON } & lm2_cmr & 0.1241 & 0.0331 & 0.0068 & 0.1291 & 0.0354 & 0.0088 & 0.1465 & 0.1978 \\
\hline & lpib_cmr & 0.6757 & 0.4268 & & 0.0152 & 0.0047 & & 0.1094 & 0.21338 \\
\hline \multirow{2}{*}{ GABON } & Im2_gab & 0.0432 & 0.0189 & 0.0082 & 0.0586 & 0.0273 & 0.0134 & 0.2258 & 0.34 \\
\hline & lpib_gab & 0.0057 & 0.0013 & 0.0001 & 0.0098 & 0.0024 & 0.0002 & 0.085 & 0.204 \\
\hline \multirow{2}{*}{ CONGO } & lm2_congo & 0.0001 & 0.0000 & & 0.0001 & 0.0000 & & 0.156 & 0.156 \\
\hline & lpib_congo & 0.0539 & 0.0152 & 0.0061 & 0.0533 & 0.0154 & 0.0061 & 0.0797 & 0.217 \\
\hline \multirow{2}{*}{ CHAD } & Im2_tchad & 0.0024 & 0.0004 & & 0.0036 & 0.0005 & & 0.124 & 0.12 \\
\hline & lpib_tchad & 0.0009 & 0.0003 & 0.0001 & 0.0009 & 0.0003 & 0.0000 & 0.0452 & 0.307 \\
\hline \multirow{2}{*}{ CAR } & lm2_rca & 0.0002 & 0.0001 & & 0.0000 & 0.0001 & & 0.0943 & 0.314 \\
\hline & lpib rca & 0.0000 & 0.0000 & 0.0000 & 0.0000 & 0.0000 & 0.0000 & 0.06528 & 0.06564 \\
\hline
\end{tabular}

Notes: Model 3, model with a trend and constant; Model 2, model with only a constant; and Model 1 has no trend and no constant. 


\subsubsection{Cointegration Tests}

Before testing the long run neutrality assumption, it is of interest to examine the existence of a long-term relationship between real output and nominal money. To this end, we use the [13] test.

The results of this test on the actual product and the nominal money supply are shown in Table 2 . We use the trace and the maximum eigenvalue tests for the null hypothesis of no cointegration. The results indicate that the null hypothesis is rejected for all countries except for
Gabon. These results are also confirmed by [14] cointegration test. Thus, the long run neutrality hypothesis is examined only for Cameroon, Central African Republic, Chad and Congo.

\subsection{Neutrality of Money Supply}

Figures 1-4 present estimates of $\gamma_{y m}$ for a wide range of values of $\lambda_{m y}$ (Panel A), $\lambda_{y m}$ (Panel B) and $\gamma_{m y}$ (Panel C) for confidence interval at 95\%. Long run

Table 2. Johansen cointegration tests.

\begin{tabular}{ccccccccc}
\hline & Hypothesized & & Trace & 0.05 & & Max-Eigen & 0.05 \\
\cline { 2 - 8 } & No. of CE(s) & Eigenvalue & Statistic & Critical Value & Prob. $^{* *}$ & Statistic & Critical Value $^{*}$ Prob. ${ }^{* *}$ \\
\hline \multirow{2}{*}{ CAMEROON } & None & 0.173859 & 10.38041 & 15.49471 & 0.2526 & 6.875629 & 14.26460 & 0.5040 \\
& At most 1 & 0.092766 & 3.504780 & 3.841466 & 0.0612 & 3.504780 & 3.841466 & 0.0612 \\
CONGO & None & 0.271751 & 11.59497 & 15.49471 & 0.1774 & 11.41603 & 14.26460 & 0.1346 \\
& At most 1 & 0.004958 & 0.178935 & 3.841466 & 0.6723 & 0.178935 & 3.841466 & 0.6723 \\
\multirow{2}{*}{ GABON } & None & 0.307548 & 24.79362 & 20.26184 & $0.0110^{*}$ & 13.59811 & 15.89210 & 0.1109 \\
& At most 1 & 0.261092 & 11.19551 & 9.164546 & $0.0203^{*}$ & 11.19551 & 9.164546 & $0.0203^{*}$ \\
CAR & None & 0.150090 & 9.278726 & 15.49471 & 0.3402 & 6.017103 & 14.26460 & 0.6110 \\
& At most 1 & 0.084378 & 3.261623 & 3.841466 & 0.0709 & 3.261623 & 3.841466 & 0.0709 \\
CHAD & None & 0.175898 & 7.249399 & 15.49471 & 0.5488 & 7.158050 & 14.26460 & 0.4706 \\
& At most 1 & 0.002466 & 0.091349 & 3.841466 & 0.7625 & 0.091349 & 3.841466 & 0.7625 \\
\hline
\end{tabular}

Notes: ${ }^{*}$ denotes rejection of the hypothesis at the 0.05 level; ${ }^{* *}$ MacKinnon-Haug-Michelis (1999) p-values.
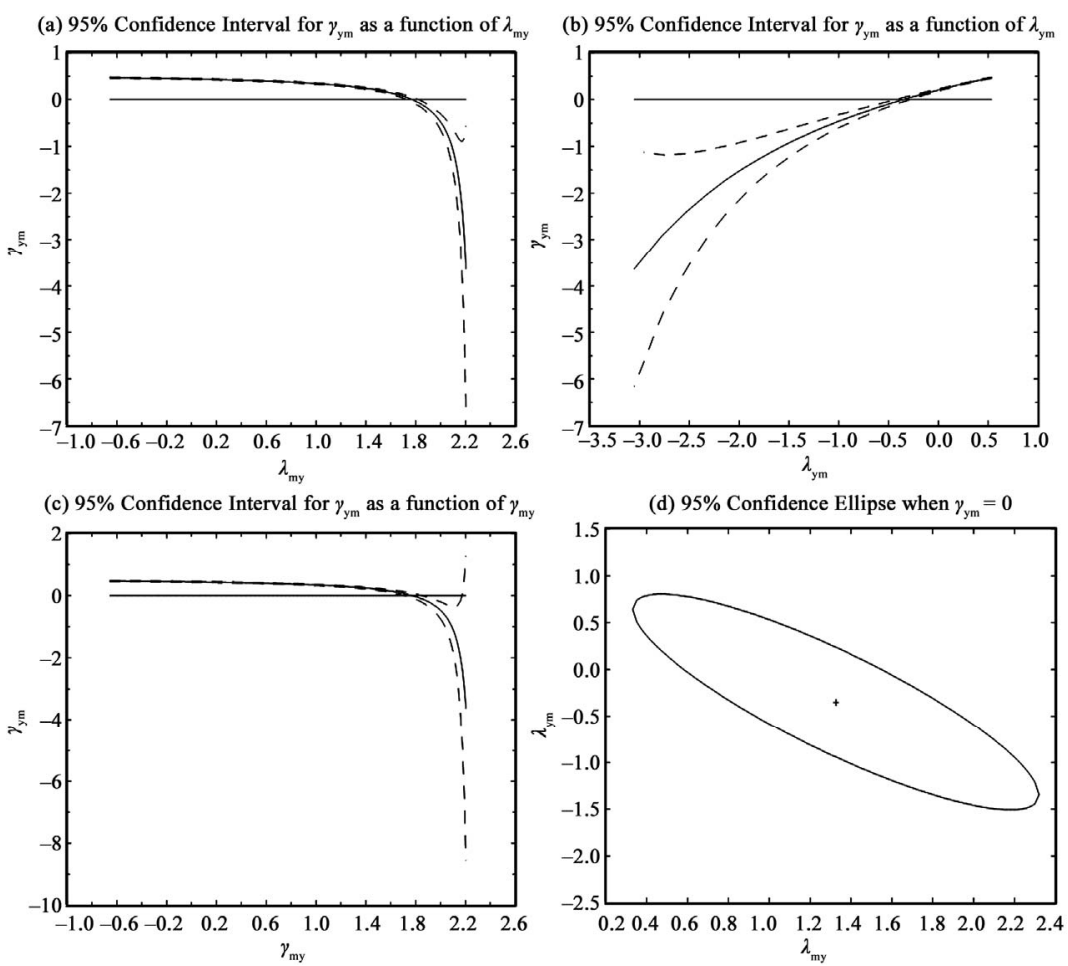

Figure 1.Confidence intervals for Cameroon. 
(a) $95 \%$ Confidence Interval for $\gamma_{y m}$ as a function of $\lambda_{m y}$
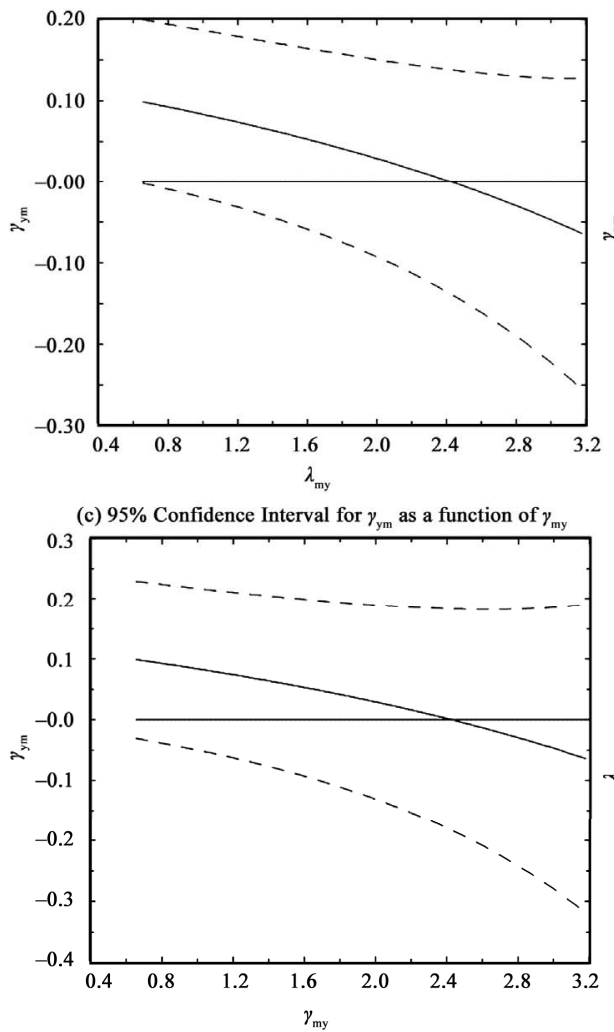

(b) $95 \%$ Confidence Interval for $\gamma_{y \mathrm{~m}}$ as a function of $\lambda_{\mathrm{ym}}$

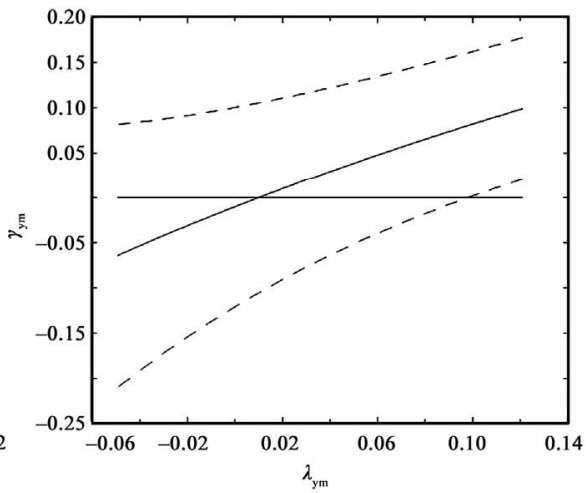

(d) $95 \%$ Confidence Ellipse when $\gamma_{y m}=0$

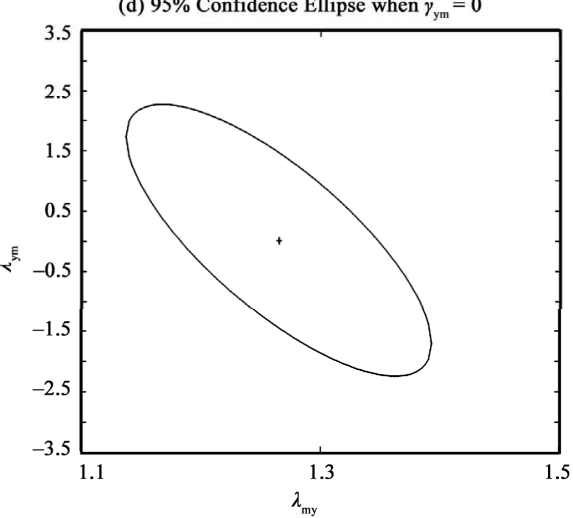

Figure 2. Confidence intervals for Central African Republic.
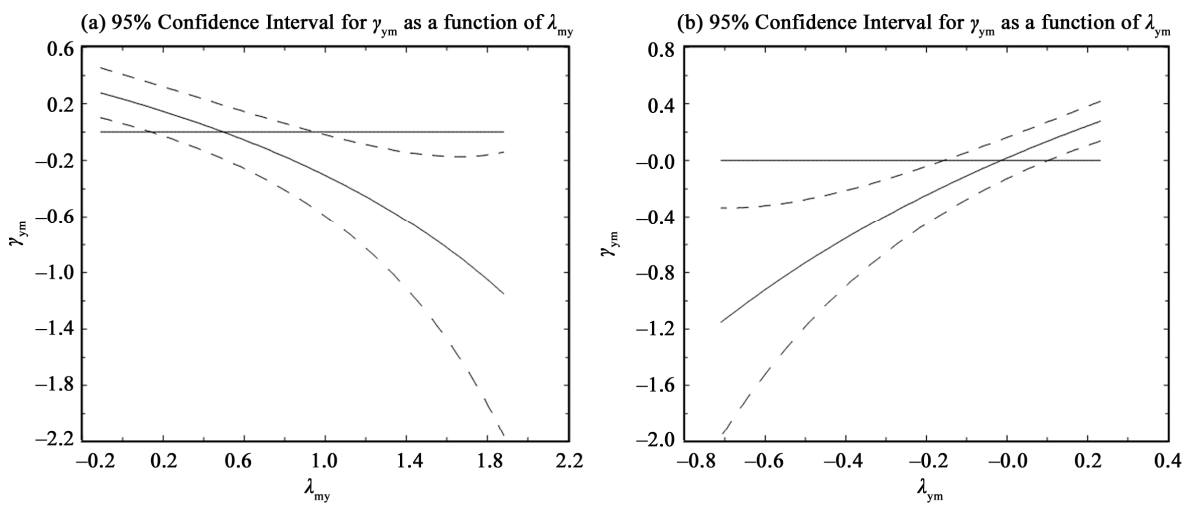

(c) $95 \%$ Confidence Interval for $\gamma_{y m}$ as a function of $\gamma$

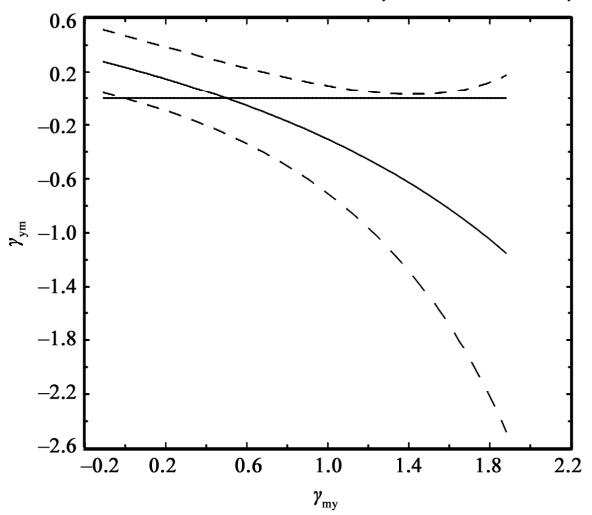

(d) $95 \%$ Confidence Ellipse when $\gamma_{\mathrm{ym}}=0$

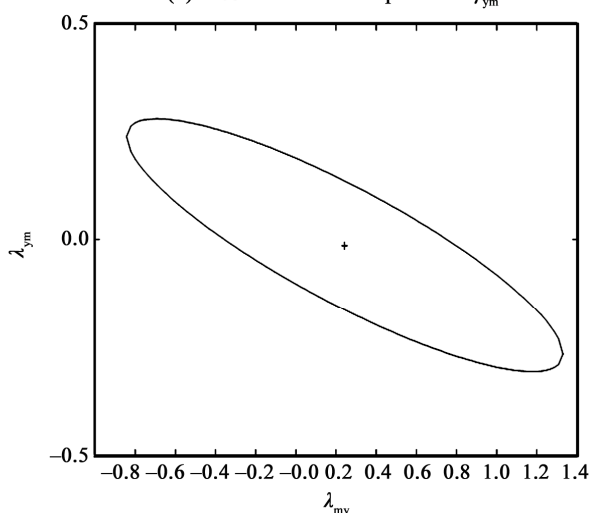

Figure 3. Confidence intervals for Chad. 

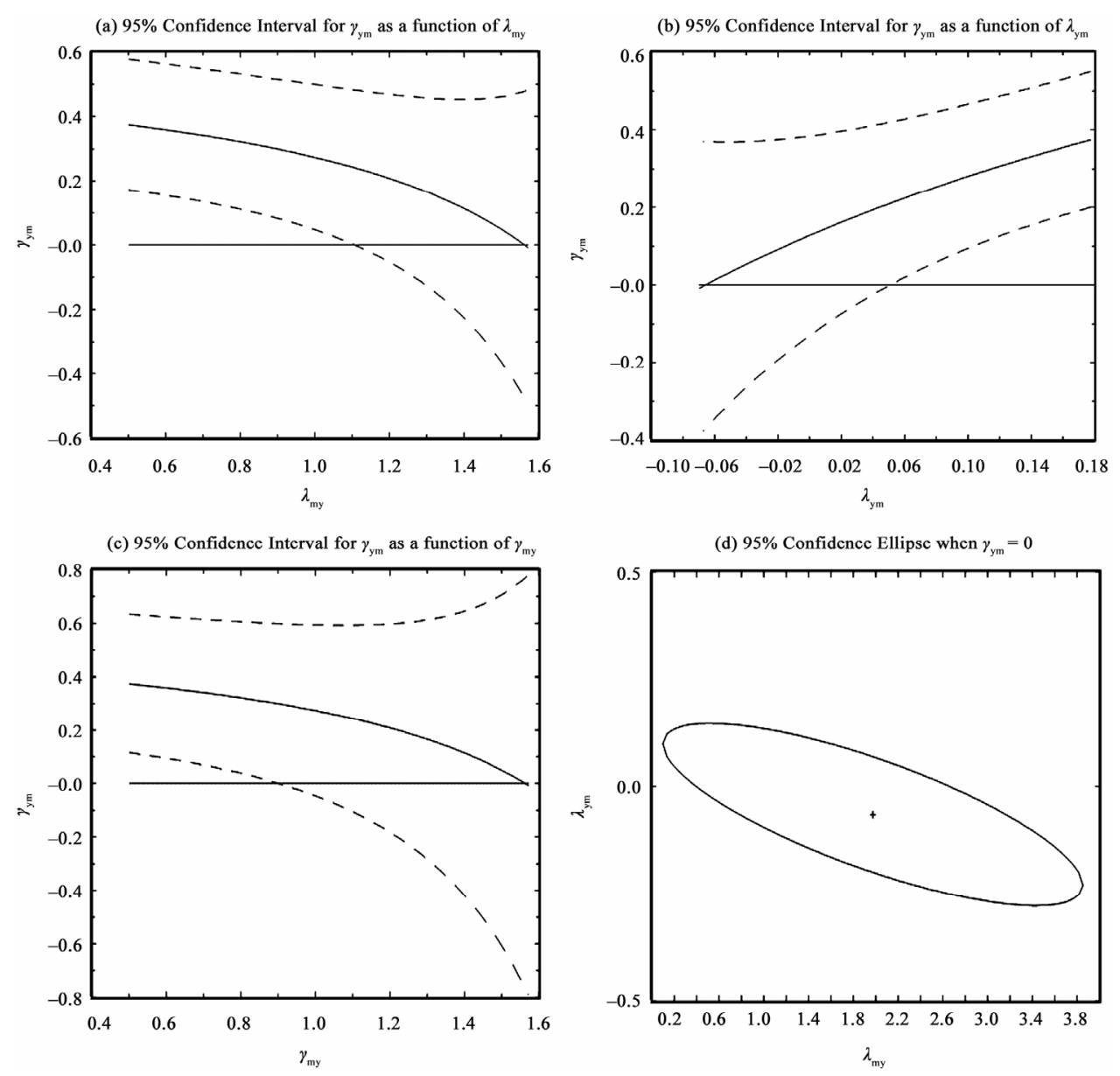

Figure 4. Confidence intervals for Congo.

neutrality is not rejected at a level of $5 \%$ if $\gamma_{y m}=0$ is within the confidence interval at $95 \%$. As for panel D, it states that when the assumption of long-run neutrality is not rejected, the ellipse covers the actual values of $\left(\lambda_{y m}, \lambda_{m y}\right)$ at $95 \%$.

\subsubsection{Cameroon}

Results of long run money neutrality for Cameroon are in Figure 1. Panel A indicates that $\lambda_{m y}<1.8$; thus we reject the long run money neutrality assumption. As to Panel B, we reject the hypothesis $\gamma_{y m}=0$ when $\gamma_{y m}>0$. On the other hand, we reject the null hypothesis of long run money neutrality based on Panel $\mathrm{C}$ result since $\gamma_{m y}<1.5$.

\subsubsection{Central African Republic}

Central African Republic results are reported in Figure 2. Results of $\lambda_{m y}$ (Panel A), $\lambda_{y m}$ (Panel B) and $\gamma_{m y}$ (Panel C) are such that related confidence intervals do not contain $\gamma_{y m}=0$. Thus the long run money neutrality assumption is rejected. Indeed, we reject $\gamma_{y m}=0$ for $\lambda_{\text {my }}<2.2$ (Panel A), $\lambda_{y m}>0.02$ (Panel B) and $\lambda_{m y}<2.2$ (Panel C).

\subsubsection{Chad}

For Chad, results are reported in Figure 3. The long run money neutrality assumption is once again rejected for $\lambda_{\text {my }}<0.3$ (Panel A), $\lambda_{y m}>0.1$ (Panel B) and $\gamma_{m y}<0.4$ (Panel C).

\subsubsection{Congo}

Results for long run money neutrality for Congo are presented in Figure 4. Based on Panel A results, we reject the long run money neutrality assumption since $\lambda_{m y}<1.1$. The same conclusion is reached using results in Panels B and C (testing the hypothesis $\gamma_{y m}=0$ ) since $\lambda_{m y}>0.06$ and $\lambda_{m y}<0.3$ respectively.

\section{Final Remarks}

We examined the long-term money neutrality on the actual output in the case of Cameroon, Central African Republic, Chad, Congo and Gabon are using annual data covering the period 1970-2008. To this end, we used the approach of [8], with a specific emphasis on unit root and cointegration issues. The results indicate a cointegrating relationship between money and real output only for 
Cameroon, the Central African Republic, Chad and Congo.

On the other hand, the empirical evidence shows that the assumption of long run money neutrality is rejected for the above countries. That means permanent changes in the money supply do have long run effects on the actual product in the above countries.

The implication of the above results is that in the context of low economic growth that characterizes CAMEU economies, their Central Bank's monetary stability strategy could be non-credible. So, it seems that the Central Bank should pursue an objective of stabilization of the product, along with the objective of monetary stability.

\section{REFERENCES}

[1] M. Friedman, "Inflation: Causes and Consequences," Asia Publishing House, New York, 1963.

[2] R. Lucas, "Expectations and the Neutrality of Money," Journal of Economic Theory, Vol. 4, No. 6, 1972, pp. 103124. doi:10.1016/0022-0531(72)90142-1

[3] R. Lucas, “Nobel Lecture: Monetary Neutrality,” Journal of Political Economy, Vol. 104, No. 2, 10996, pp. 661682.

[4] T. Sargent and N. Wallace, "Rational Expectations, the Optimal Monetary Instrument, and the Optimal Money Supply Rule,” Journal of Political Economy Vol. 83, No. 2, 1975, pp. 241-254. doi:10.1086/260321

[5] J. Boschen and C. Otrok, "Long-Run Neutrality and Super-Neutrality in an ARIMA Framework: Comment," American Economic Review, Vol. 84, No. 3, 1994, pp.
1470-1473.

[6] J. B. Bullard, “Testing Long-Run Monetary Neutrality Propositions: Lessons from the Recent Research,” Federal Reserve Bank of St. Louis Review, Vol. 81, No. 6, 1999, pp. 57-77.

[7] P. Coe and J. Nason, “The Long-Horizon Regression Approach to Monetary Neutrality: How Should the Evidence Be Interpreted?” Economics Letters, Vol. 1, No. 78, 2003, pp. 351-356. doi:10.1016/S0165-1765(02)00263-X

[8] R. G. King and M. W. Watson, "Testing Long-Run Neutrality," Federal Reserve Bank of Richmond Economic Quarterly, Vol. 83, No. 3, 1997, pp. 69-101.

[9] R. Lucas, "Two Illustrations of the Quantity Theory of Money,” American Economic Review, Vol. 70, No. 5, 1980, pp. 1005-1014.

[10] S. Miyagawa and Y. Morita, "The Fisher Effect and the Long-Run Phillips Curve in the Case of Japan, Sweden and Italy,” Working Papers in Economics, No. 77, 2003.

[11] S. W. Chen, "Evidence of the Long-Run Neutrality of Money: The Case of South Korea and Taiwan,” Economics Bulletin, Vol. 3, No. 64, 2007, pp. 1-18.

[12] T. Mvondo, "L'hypothèse de Neutralité monEtaire: Une Application en Zone Franc,” Thèse pour le Doctorat en Sciences Economiques, Université Nancy, Nancy, 2011.

[13] S. Johansen, "Statistical Analysis of Cointegration Vectors," Journal of Economic Dynamics and Control, Vol. 12, No. 2-3, 1988, pp. 231-254. doi:10.1016/0165-1889(88)90041-3

[14] R. Engle and C. W. J. Granger, "Cointegration and Error Correction: Representation, Estimation and Testing," Econometrica, Vol. 55, No. 2, 1987, pp. 251-276. doi:10.2307/1913236 